\title{
MODEL PEMBERDAYAAN WILAYAH PESISIR DALAM MENGHADAPI PASAR BEBAS MASYARAKAT EKONOMI ASEAN*
}

\author{
Hezron Sabar Rotua Tinambunan**
}

Bagian Ilmu Hukum

Fakultas Ilmu Sosial dan Hukum Universitas Negeri Surabaya, Surabaya

Jalan Ketintang Surabaya Jawa Timur 60231

\begin{abstract}
The role of the people are needed to the development, because development success in a country is how the government to make a empowerment community. Local government policy in development has contributed by doing upaya-upaya serious. More indonesia is facing Asean economic community (MEA) in 2016, aimed at as an effort to increase stability the economy in Asean. Continuity of the local government and communities to face the challenges MEA indispensable. Local governments have to make regulatory system warehouse related resinous to cut the tengkulak a highly lethal businesses fishermen in guarantees the availability of capital for the production of sustainable and stabilize commodity prices.
\end{abstract}

Keywords: fishermen, local governments, Asean economic community.

\section{Intisari}

Peran masyarakat sangat dibutuhkan untuk tercapainya pembangunan, karena keberhasilan pembangunan di suatu negara adalah bagaimana pemerintah menentukan model pemberdayaan kepada masyarakatnya. Kebijakan Pemerintah Daerah dalam pembangunan memiliki andil dengan melakukan upaya-upaya serius. Lebih lagi Indonesia menghadapi Masyarakat Ekonomi ASEAN (MEA) pada tahun 2016, yang bertujuan sebagai salah satu upaya untuk meningkatkan stabilitas perekonomian di kawasan ASEAN. Kesinambungan antara pemerintah daerah dan masyarakat guna menghadapi tantangan MEA sangat diperlukan. Pemerintah daerah harus membuat regulasi terkait sistem resi gudang guna memangkas jalur tengkulak yang sangat mematikan hasil usaha nelayan dalam menjamin ketersediaan modal usaha untuk produksi yang berkelanjutan dan menstabilkan harga komoditi.

Kata kunci: nelayan, pemerintah daerah, Masyarakat Ekonomi ASEAN.

\section{Pokok Muatan}

A. Latar Belakang Masalah 251

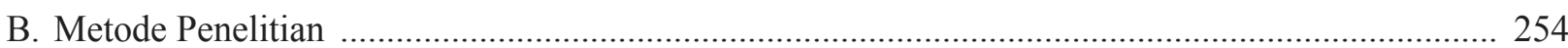

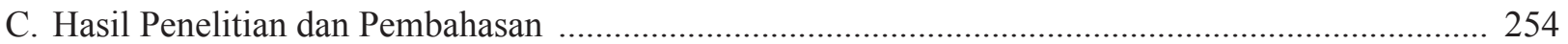

1. Kebijakan Penguatan Budaya Maritim Desa Pesisir Oleh Pemerintah Provinsi Jawa Timur dalam Menghadapi Masyarakat Ekonomi ASEAN (MEA)

2. Faktor-Faktor yang Menjadi Kendala Penguatan Budaya Maritim Desa Pesisir di Jawa Timur dalam Menghadapi Masyarakat Ekonomi ASEAN (MEA) ....................................................... 257

D. Kesimpulan 


\section{A. Latar Belakang Masalah}

Indonesia merupakan Negara Kepulauan dengan jumlah pulau yang mencapai 17.508 dan panjang garis pantai kurang lebih $81.000 \mathrm{Km}$. Keadaan ini menyebabkan kawasan pesisir menjadi andalan sumber pendapatan masyarakat Indonesia. Secara umum, wilayah pesisir dapat didefenisikan sebagai wilayah pertemuan antara ekosistem darat, ekosistem laut dan ekosistem udara yang saling bertemu dalam suatu keseimbangan yang rentan. ${ }^{1}$

Posisi geografis kepulauan Indonesia sangat strategis karena merupakan pusat lalu lintas maritim antar benua. Indonesia juga memiliki kedaulatan terhadap laut wilayahnya meliputi; perairan pedalaman, perairan nusantara, dan laut teritorial (sepanjang 12 mil dari garis dasar). Disamping itu ada juga zona tambahan Indonesia, yang memiliki hak-hak berdaulat dan kewenangan tertentu. Selain itu, ada juga Zona Ekonomi Eksklusif Indonesia (ZEEI) sejauh 200 mil dari garis pangkal, dimana Indonesia mempunyai hak-hak berdaulat atas kekayaan alam (perikanan), kewenangan untuk meme-lihara lingkungan laut, mengatur dan mengizinkan penelitian ilmiah kelautan, pemberian ijin pembangunan pulau-pulau buatan, instalasi dan bangunan lainnya. ${ }^{2}$

Kekayaan sumber daya laut yang melimpah merupakan ciri tersendiri bagi negara Indonesia. Indonesia sebagai Negara kepulauan (archipelagic state) terbesar di dunia, Indonesia memiliki \pm 17.480 pulau dengan luas lautnya mencapai 5,8 juta $\mathrm{km}^{2}$ dengan garis pantai sepanjang $\pm 95,181$ $\mathrm{km}^{2}$. Negara kepulauan berarti suatu negara yang seluruhnya terdiri atas satu atau lebih kepulauan dan dapat mencakup pulau lain. ${ }^{3}$ Wilayah perairan laut yang dimiliki Indonesia lebih luas dari pada wilayah daratannya, sehingga peranan wilayah laut menjadi sangat penting bagi kehidupan bangsa dan negara.

Indonesia memiliki wilayah laut teritorial seluas 3.2 juta $\mathrm{Km}^{2}$, dengan garis pantai sepanjang $95.181 \mathrm{~km}^{2}$ serta 2.9 juta $\mathrm{km}^{2}$ laut perairan Zona Ekonomi Esklusif (ZEE), dengan demikian total wilayah perairan Indonesia adalah $77 \%$ dari seluruh luas Indonesia. Potensi geografis inilah yang menjadi dasar menetapkan kebijakan untuk menjadikan Indonesia menjadi Negara maritim. ${ }^{4}$ Untuk membangun kemandirian tersebut terdapat 5 hal yang perlu dimiliki untuk mewujudkan Negara Maritim. Pertama, character buiding and nation buliding sebagai bangsa yang memiliki orientasi pembangunan negara dari land based oriented National Development; Kedua, strategi ekonomi keluar dari keterpurukan dengan menjadikan sektor kelautan dan perikanan sebagai sektor kelautan dan perikanan sebagai sektor andalan (leading sector); Ketiga, konsistensi implementasi; Keempat, lingkungan sosial dan politik yang kondusif; dan Kelima, law enforcement dan pengamanan wilayah laut. $^{5}$

Budaya maritim yang kuat sudah sepatutnya dimiliki oleh negara kepulauan. Hal tersebut terlihat pada sejarah maritim Indonesia pada masa lampau, yang menunjukkan bagaimana kerajaan Sriwijaya dan Majapahit merupakan contoh nyata kejayaan pemerintahan maritim di Nusantara. Paradigma masyarakat pada masa itu mampu menciptakan visi maritim sebagai bagian utama dari kemajuan budaya, ekonomi, politik, sosial dan pertahanan. Kemampuan tersebut dilakukan dengan segenap political will dari seluruh pemimpin dan rakyatnya.

Kejayaan pada masa lalu berbanding terbalik

\footnotetext{
Muhamad Dio Fabianto dan Pieter Th Berhitu, "Konsep Pengelolaan Wilayah Pesisir Secara Terpadu dan Berkelanjutan yang Berbasis Masyarakat", Jurnal Teknologi, Vol. 11, No. 2, 2014, hlm. 2054.

Ridwan Lasabuda, "Pembangunan Wilayah Pesisir dan Lautan dalam Perspektif Negara Kepulauan Republik Indonesia", Jurnal Ilmiah Platax, Vol. I-2, Januari 2013, hlm. 93.

Lihat Dhiana Puspitawati, "Desentralisasi Pengelolaan Wilayah Pesisir dan Lautan dalam Kerangka Prinsip Negara Kepulauan", Jurnal Arena Hukum, Vol. 7, No. 2, Agustus 2014, hlm. 212.

Amelya Gustina, “Analisis Transhipment Pasal 69 ayat (3) Peraturan Menteri Kelautan Perikanan No. 30 Tahun 2012 tentang Usaha Perikanan Tangkap”, Jurnal Dinamika Hukum, Vol. 14 No. 2, Mei 2014, hlm. 340.

Lihat Prakoso Bhairawa Putera, "Perspektif dan Peran Ilmu Pengetahuan dan Teknologi dalam Membangun Kemandirian Bangsa pada Tatanan Negara Maritim“, Inovasi: Jurnal Politik dan Kebijakan, Vol. 10, No. 2, Juni 2013, hlm 139.
} 
dengan kondisi Indonesia dewasa ini. Potensi laut saat ini belum dimanfaatkan secara optimal. Indonesia sebagai negara hukum, secara normatif kekayaan sumberdaya tersebut dikuasai oleh Negara untuk dikelola sedemikian rupa dalam mewujudkan kesejahteraan masyarakat. ${ }^{6}$ Berlimpahnya potensi sumber daya alam di negeri ini masih menyisakan masalah ekonomi yang berkepanjangan yaitu kemiskinan. ${ }^{7}$ Penelitian yang dilakukan oleh Ambariyanto dan Denny N.S, menyebutkan terdapat empat persoalan yang dihadapi wilayah pesisir di Indonesia secara umum, yakni:

(1) Tingginya tingkat kemiskinan masyarakat pesisir, tercatat pada tahun 2010 kemiskinan di desa-desa pesisir mencapai angka 7 juta jiwa yang terdapat 10.639 desa pesisir;

(2) Tingginya kerusakan sumberdaya pesisir;

(3) Rendahnya kemandirian organisasi sosial desa dan lunturnya nilai-nilai budaya lokal; dan

(4) Rendahnya infrastruktur desa dan kesehatan lingkungan pemukiman. Keempat persoalan pokok ini juga memberikan andil terhadap tingginya kerentanan terhadap bencana alam dan perubahan iklim yang cukup tinggi pada desa-desa pesisir. ${ }^{8}$

Kondisi di atas semakin krusial dengan lemahnya dukungan peraturan perundang-undangan pengelolaan sumberdaya pesisir dan laut yang selama ini dirasa belum menampung semua aspirasi stakeholder dan kebanyakan masih bersifat sektoral dan tidak memihak kepentingan masyarakat pesisir dan kelestarian sumberdayanya. Salah satu tujuan dibentuknya Undang-Undang Nomor 1 Tahun 2014 Tentang Perubahan Atas Undang-Undang Nomor
27 Tahun 2007 tentang Pengelolaan Wilayah Pesisir dan Pulau-Pulau Kecil yaitu memperkuat peran serta masyarakat dan lembaga pemerintah serta mendorong inisiatif masyarakat dalam pengelolaan Sumber Daya Pesisir dan Pulau-Pulau Kecil agar tercapai keadilan, keseimbangan dan keberlanjutan. ${ }^{9}$

Peran masyarakat desa pesisir dan pemerintah sangat dibutuhkan untuk tercapainya pembangunan kembali budaya maritim guna mewujudkan kejayaan lautan. Kehidupan di negara kepulauan berciri maritim, memanfaatkan laut sebagai sumber hidupnya. Sumber daya laut dari sudut ekonomi mempunyai keunggulan komparatif, sedangkan posisinya dapat menjadi keunggulan positif. ${ }^{10}$ Hal tersebut senada dengan Agenda Pembanguan Nasional dalam Rencana Pembangunan Jangka Menengah Nasional 2015-2019 (selanjutnya disebut RPJMN) yang salah satunya memperkuat jatidiri sebagai negara maritim. ${ }^{11}$

Pembangunan Kawasan Perdesaan dilakukan oleh Pemerintah, Pemerintah Daerah Provinsi, dan Pemerintah Daerah Kabupaten/Kota melalui satuan kerja perangkat daerah, Pemerintah Desa, dan/atau Badan Usaha Milik Desa dengan mengikutsertakan masyarakat Desa. ${ }^{12}$ Pembangunan kawasan perdesaan yang dimaksud dalam ketentuan yang ada dalam Undang-undang Nomor 6 Tahun 2014 tentang Desa (selanjutnya disebut UU Desa) tersebut diartikan secara luas, tidak terkecuali dengan desa pesisir. Kebijakan yang dibuat oleh Pemerintah Daerah sangat berpengaruh dalam pencapaian kesejahteraan masyarakat desa pesisir dalam melakukan pemanfaatan sumber daya alam laut yang dimiliki.

Kebijakan desentralisasi yang diatur dalam

\footnotetext{
Lihat Pasal 33 ayat (3) Undang-Undang Dasar Negara Republik Indonesia Tahun 1945.

Endang Sutrisno, "Implementasi Pengelolaan Sumber Daya Pesisir Berbasis Pengelolaan Wilayah Pesisir Secara Terpadu untuk Kesejahteraan Nelayan", Jurnal Dinamika Hukum, Vol. 14, No. 1, Januari 2014, hlm. 2.

Ambariyanto dan Denny N.S, “Kajian Pembangunan Desa Pesisir Tangguh di Kota Semarang”, Jurnal Riptek, Vol. 6, No. II, 2012, hlm. 29. Lihat Pasal 4 huruf c Undang-Undang Nomor 27 Tahun 2007 Tentang Pengelolaan Wilayah Pesisir dan Pulau-Pulau Kecil (Lembaran Negara Republik Indonesia Tahun 2007 Nomor 84, Tambahan Lembaran Negara Republik Indonesia Tahun 2007 Nomor 4739).

10 Wahyono S.K., 2009, Indonesia Negara Maritim, dalam Masalah Perbatasan Wilayah Laut Indonesia di Laut Arafuru dan Laut Timor, Teraju, Jakarta, hlm. 169-170.

11 Kementerian Perencanaan Pembangunan Nasional, 2015, Rencana Pembangunan Jangka Menengah Nasional 2015-2019: BUKU I Agenda Pembanguan Nasional, Kementerian Perencanaan Pembangunan Nasional, Jakarta, hlm. 6-4.

12 Lihat Pasal 85 Undang-Undang Nomor 6 Tahun 2014 tentang Desa (Lembaran Negara Republik Indonesia Tahun 2014 Nomor 7, Tambahan Lembaran Negara Republik Indonesia Nomor 5495).
} 
Undang-Undang Nomor 23 Tahun 2014 tentang Pemerintahan Daerah (selanjutnya disebut UU Pemda) mengatur sistem pemerintahan daerah yang memilki hak, wewenang dan kewajiban daerah otonom untuk mengatur dan mengurus sendiri urusan pemerintahan dan kepentingan masyarakat setempat dalam sistem negara Kesatuan Republik Indonesia. Dalam Pasal 12 ayat (2) huruf g UU Pemda, mengatur bahwa pemberdayaan masyarakat dan desa merupakan bentuk urusan pemerintahan wajib yang tidak berkaitan dengan Pelayanan Dasar. Namun, terkait bidang kelautan dan perikanan sebagai bentuk urusan pilihan dari pemerintahan daerah provinsi dan pemerintahan daerah kabupaten/ kota. ${ }^{13}$ Penentuan urusan pilihan ditentukan dengan skala priorotas yang ditetapkan oleh pemerintahan daerah, karena tidak ada suatu kewajiban bagi pemerintah daerah dalam membentuk kebijakan terkait hal tersebut.

Dewasa ini masih ditemukan banyak ketimpangan antara desa/kelurahan sesuai dengan data Kementerian Dalam Negeri Tahun 2013, tercatat jumlah administrasi desa mencapai 72.944 dan administrasi kelurahan sebanyak 8.309, sehingga total desa/kelurahan saat ini sejumlah 81.253 desa/kelurahan. Sebanyak kurang lebih 32 ribu desa dan didalamnya termasuk desa maritim, masuk dalam arsiran daerah yang memerlukan perhatian khusus dari pemerintah. Oleh karena itu, UU Desa memiliki dua tujuan besar yaitu, perluasan kesejahteraan dan mereduksi disparitas wilayah. UU Desa ini, diharapkan menjadi salah satu lompatan sejarah dalam proses pembangunan yang sedang berlangsung. Dalam rangka memfasilitasi implementasi UU Desa di Jawa Timur, maka Pemerintah Provinsi Jawa Timur mempunyai peran yang sangat strategis untuk memfasilitasi Pemerintah Kabupaten/Kota tentang Desa, meningkatkan kapasitas Aparatur Pemerintahan
Desa, menetapkan bantuan keuangan kepada Desa dan melakukan upaya-upaya percepatan atau akselerasi pembangunan perdesaan di Jawa Timur.

Jawa Timur memiliki wilayah pesisir yang sangat luas. Wilayah tersebut mempunyai potensi sumber daya alam yang cukup beragam, diantaranya potensi perikanan, budidaya tambak, industri pengelolaan ikan, peternakan, perkebunan dan wisata pantai. Surabaya, Sidoarjo, dan Gresik merupakan Kota/Kabupaten di Jawa Timur yang juga memiliki wilayah pesisir. Namun, ketiga daerah tersebut lebih dikenal dengan wilayah industri, dengan kata lain potensi yang ada di wilayah pesisir belum di explore semaksimal mungkin. Hal ini menunjukan bahwa belum sepenuhnya wilayah pesisir dan potensi yang ada desa pesisir sudah termanfaatkan dengan baik.

Indonesia akan menghadapi Masyarakat Ekonomi Asean (selanjutnya disebut MEA) pada tahun 2016. Tujuan dibentuknya Komunitas Ekonomi ASEAN sebagai salah satu pilar dari tiga pilar Komunitas ASEAN adalah salah satunya untuk meningkatkan stabilitas perekonomian di kawasan ASEAN, melalui upaya membentuk kawasan ekonomi antar negara ASEAN yang kuat, agar negara-negara yang menjadi anggota ASEAN memiliki daya saing yang makin kuat di mata dunia, khususnya di mata negara-negara di Amerika dan Eropa. MEA tak ubahkan justifikasi ekonomi politik regionalisme kapitalistik yang wataknya, "red carpet of capitalism", jalur khusus ekonomi pasar bebas di level kawasan, yang berpotensi merampok sumberdaya alam dan hak-hak masyarakat Asia Tenggara. ${ }^{14}$ Indonesia dapat melihat peluang strategis yang dimiliki sebagai negara maritim, tentu keberhasilan MEA dapat dirasakan dan menjadikan Indonesia sebagai pasar potensial dunia, yang bukan sekadar sebagai konsumen tetapi sebagai negara pengekspor.

13 Lihat Pasal 7 ayat (4) Peraturan Pemerintah Republik Indonesia Nomor 38 Tahun 2007 Tentang Pembagian Urusan Pemerintahan Antara Pemerintah, Pemerintah Daerah Provinsi, dan Pemerintah Daerah Kabupaten/Kota (Lembaran Negara Republik Indonesia Nomor 82 Tahun 2007, Tambahan Lembaran Negara Republik Indonesia Nomor 4737).

14 Herlambang P. Wiratraman, “Asean Economic Community: An Analysis of Legal Framework and Its Implementation”, Paper, Regional Workshop: Protection Of People's Right to Land and Natural Resources in Facing The Wave of ASEAN Economic Integration, Bali, 23-24 November 2014, hlm.7. 
Kebijakan Pemerintah Daerah dalam pembangunan desa pesisir memiliki andil dengan melakukan upaya-upaya serius. Kebijakan yang ada diharapkan dapat menciptakan iklim ekonomi kondusif dan menggali potensi yang ada di desa pesisir. Penguatan budaya maritim di daerah yang budaya maritimnya mulai luntur perlu dilakukan seperti di Kota Surabaya, Kabupaten Sidoarjo, dan Kabupaten Gresik.

Faktor produktivitas akan menjadi kunci bagaimana Indonesia khususnya Jawa Timur dalam menghadapi MEA. Secara logika sederhana, produktivitas adalah kunci utama dalam persaingan. Produktivitas yang tinggi diharapkan produksi lebih efisien dan dapat memberikan harga lebih kompetitif. ${ }^{15}$ Posisi strategis yang dimiliki sebagai jalur perdagangan internasional seharusnya Indonesia berpotensi untuk dapat memainkan peranan politisnya dalam percaturan politik Internsional. Hal tersebut tentu ketika daerah-daerah di Indonesia, seperti halnya Jawa Timur dapat memainkan perannya untuk mengelola potensi yang ada di darat dan juga di laut. Berdasarkan latar belakang diatas, maka dirumuskan masalah sebagai berikut: Pertama, Bagaimana kebijakan penguatan budaya maritim Desa Pesisir oleh Pemerintah Provinsi Jawa Timur dalam menghadapi Masyarakat Ekonomi ASEAN (MEA) ? Kedua, Faktorfaktor apa saja yang menjadi kendala penguatan budaya maritim Desa Pesisir di Jawa Timur dalam menghadapi Masyarakat Ekonomi ASEAN (MEA)?

\section{B. Metode Penelitian}

Penelitian ini merupakan penelitian kualitatif dengan pendekatan yuridis sosiologis dan penelitian terhadap hukum sebagai law in action, merupakan studi ilmu sosial yang non doktrinal dan bersifat empiris. Dalam penelitian non doktrinal, perhatian peneliti akan terfokus pada Pemerintah Kabupaten Banyumas (Badan Penanaman Modal dan Pelayanan
Perizinan (BPMPP)), stake holder dan Masyarakat (DPRD Kabupaten Banyumas). Spesifikasi penelitian ini bersifat deskriptif dengan sumber data berupa manusia dengan tingkah lakunya, peristiwa, dokumen, dan arsip. Lokasi penelitian dilakukan di Kabupaten Banyumas dengan penentuan sampel lokasi dan informan penelitian secara purposive sampling. Data dikumpulkan dengan metode interaktif dan non interaktif dan dianalisis dengan model analisis interaktif dan analisis mengalir (flow model) sedangkan validitas data menggunakan triangulasi sumber.

\section{Hasil Penelitian dan Pembahasan}

1. Kebijakan Penguatan Budaya Maritim Desa Pesisir Oleh Pemerintah Provinsi Jawa Timur dalam Menghadapi Masyarakat Ekonomi ASEAN (MEA)

Tahun 2015 merupakan tahun istimewa bagi Negara-Negara yang tergabung dalam Association of South East Asian Nations (ASEAN). Betapa tidak? Karena di tahun 2015 inilah mulai diberlakukan ASEAN Community 2015 (Komunitas ASEAN 2015), adalah upaya mengintegrasikan NegaraNegara ASEAN dalam suatu komunitas bersama dalam rangka mendorong terciptanya kekompakan, kesamaan visi satu tujuan, kesejahteraan bersama, dan saling peduli di antara Negara-Negara di kawasan Asia Tenggara. ${ }^{16}$ Jadi Komunitas ASEAN 2015 bertujuan mendorong terciptanya kebersamaan, kesamaan visi, kesejahteraan, dan saling peduli diantara Negara-Negara di Kawasan Asia Tenggara untuk menghadapi negara-negara lain di dunia. Dengan asumsi bahwa dalam rangka mengadapi persaingan dengan Negara-Negara di dunia, ASEAN lebih berpeluang memiliki daya saing tinggi apabila bergabung dalam suatu komunitas bersama.

Terdapat tiga pilar dari Masyarakat ASEAN 2015, yaitu: (1) Komunitas Politik dan Keamanan

15 PKRB-BKF, 2014, Analisa Daya Saing dan Produktivitas Indonesia Menghadapi MEA, Riset Kajian PKRB, Kementerian Keuangan Republik Indonesia, Jakarta, hlm. 2.

16 Dahlan Iskan, "Komunitas ASEAN 2015: Membangun Kebersamaan untuk Satu Tujuan”, Makalah, Seminar Nasional Menghadapi ASEAN Community, Jawa Pos, Surabaya, 2011, hlm. 1. 
ASEAN; (2) Komunitas Ekonomi ASEAN; (3) Komunitas Sosial Budaya ASEAN. Di antara ke tiga pilar tersebut yang kemudian paling popular adalah Komunitas EkonomiASEAN atau yang di Indonesia terkenal denga istilah Masyarakat Ekonomi Asean. Tujuan dibentuknya Komunitas Ekonomi ASEAN (yang merupakan salah satu pilar dari tiga pilar Komunitas ASEAN) tidak lain untuk meningkatkan stabilitas perekonomian di kawasan ASEAN melalui upaya membentuk kawasan ekonomi antar negara ASEAN yang kuat, agar karenanya negara-negara yang menjadi anggota ASEAN memiliki daya saing yang makin kuat di mata dunia, khususnya di mata Negara-Negara di Amerika dan Eropa. Saat ini di Amerika dan Eropa masih mengalami krisis ekonomi, dan dengan terbentuknya Komunitas Ekonomi ASEAN diharapkan akan bisa mengatasi masalah-masalah dalam bidang perekonomian antar negara ASEAN. Jangan sampai kasus krisis ekonomi seperti di Indonesia pada tahun 1997 dulu terulang kembali.

Latar belakang Indonesia sebagai negara kepulauan sepatutnya memiliki budaya maritim yang kuat, baik dalam cara hidup bermasyarakat maupun kebijakan pembangunan nasionalnya. Budaya maritim secara perlahan memudar dan hingga kini Indonesia masih berorientasi ke darat. Hingga pemerintahan baru oleh Presiden Joko Widodo yang ingin mewujudkan Indonesia sebagai poros maritim dunia dengan Rencana Pembangunan Jangka Menengah Nasional Tahun 2015-2019. Terdapat lima pilar yang menjadi perhatian lebih dalam mewujudkan hal tersebut, yang salah satunya adalah membangun budaya maritim Indonesia.

Kebijakan pengembangan kawasan budidaya dan strategi pengembangan kawasan pesisir dan pulau-pulau kecil dilakukan melalui upaya pengembangan kawasan budi daya sesuai dengan karakter dan daya dukung yang dimiliki, terutama untuk mendukung pemantapan sistem metropolitan dan sistem agropolitan dalam rangka peningkatan pertumbuhan dan pemertaan kesejahteraan masyarakat. ${ }^{17}$ Lebih lanjut dalam Pasal 23 ayat (1) Peraturan Gubernur Jawa Timur Nomor 97 Tahun 2011 Tentang Rencana Strategis Wilayah Pesisir dan Pulau-Pulau Kecil Tahun 2011-2030, menyebutkan bahwa Kabupaten Gresik, Kabupaten Sidoarjo dan Kota Surabaya merupakan wilayah Kabupaten/Kota yang memiliki wilayah pesisir dan pulau-pulau kecil.

Pasal 2 Peraturan Daerah Nomor 6 Tahun 2012 Tentang Pengelolaan dan Rencana Zonasi Wilayah Pesisir dan Pulau-Pulau Kecil Tahun 2012-2032 menyebutkan bahwa kegiatan dalam pengelolaan dan rencana zonasi wilayah pesisir meliputi kegiatan, perencanaan, pemanfaatan, pengawasan dan pengendalian. Pemanfaatan dalam pengembangan wilayah meliputi peningkatan konservasi ekosistem wilayah pesisir dan pulaupulau kecil, pengoptimalan pengembangan kawasan pesisir dan pulau-pulau kecil, dan peningkatan keberlanjutan ekosistem wilayah pesisir dan pulaupulau kecil belum nampak di Provinsi Jawa Timur khususnya di Kabupaten Sidoarjo, Kabupaten Gresik dan Kota Surabaya.

Penelitian yang dilakukan di tiga Kabupaten/ Kota tersebut menunjukan kebijakan yang dibuat dalam Peraturan Daerah maupun Peraturan Gubernur masih sangat minim implementasinya. Desa Tambak Cemandi Sidoarjo dari wawancara bersama warga desa bersama pemerintahan desa dan kelompok nelayan, menunjukkan indikasi bahwa minimnya perhatian daerah kepada masyarakat pesisir. Mayoritas sendi penghidupan masyarakat desa Tambak Cemandi bertumpu pada pengelolaan tambak bandeng dan pertanian garam serta pencarian ikan oleh para nelayan menggunakan perahu kecil. Potensi sumberdaya alam desa Tambak Cemandi Sidoarjo sangat besar dengan luas desa \pm 525 hektar masih terdapat 357 warga miskin yang mendapatkan bantuan dari pemerintah, sehingga terjadi kesejangan antara potensi yang

17 Lihat Pasal 14 ayat (1) Peraturan Daerah Provinsi Jawa Timur Nomor 5 Tahun 2012 Tentang Rencana Tata Ruang Wilayah Provinsi Tahun 2011-2031 (Lembaran Daerah Provinsi Jawa Timur Tahun 2012 Nomor 3 Seri D). 
dimiliki dengan tingkat kesehjateraan masyarakat. ${ }^{18}$

Nelayan yang berada di wilayah pesisir Tambak Cemandi, hanya melaut menggunakan perahu kecil maksimal berukuran 5 GT yang hanya bisa menempuh jarak 3 kilometer dari bibir pantai ${ }^{19}$, sehingga hasil tangkapan laut yang didapatkan bukan jenis ikan yang bernilai tinggi. Kondisi tersebut diperparah ketika terjadi pendangkalan di muara laut. Berdasarkan hasil wawancara dengan ketua Kelompok Nelayan Danau Biru Bapak Kariono selama 3 (tiga) bulan terakhir nelayan tidak dapat melaut karena hasil tangkapan menurun dan jumlah pengeluaran untuk bahan perahu melebihi hasil yang tangkapan.

Kebijakan Pemerintah Provinisi Jawa Timur sendiri Kabupaten Sidoarjo termasuk kawasan minapolitan yang merupakan kawasan strategis dari sudut kepentingan ekonomi. ${ }^{20}$ Tingkat perekonomian di desa pesisir Kabupaten Sidoarjo justru tergolong rendah dan kurang mendapatkan perhatian pemerintah daerah. Masyarakat pesisir khususnya petani tambak dan petani garam, di Desa Tambak Cemandi belum merasakan dampak signifikan dari program pemerintah daerah Kabupaten Sidoarjo, khususnya Dinas Kelautan dan Perikanan. Bantuan Pemerintah Kabupaten Sidoarjo selama ini hanya sebatas penyuluhan.

Hal serupa juga terjadi di desa pesisir di wilayah Kabupaten Gresik dan Kota Surabaya. Sampel di wilayah Kabupaten Gresik yang berada di Desa Ngimboh, Kecamatan Ujung Pangkah, Kabupaten Gresik, menyatakan bahwa tidak adanya perhatian pemerintah daerah terhadap nelayan kecil. Sejumlah 500 Kepala Keluarga yang berprofesi sebagai Nelayan di daerah Ngimboh harus memutar otak untuk dapat melaut setiap harinya. Meskipun mereka tidak mendapatkan bantuan dari pemerintah, perihal modal dan perlengkapan untuk melaut, mereka masih bisa bernafas lega karena didaerah mereka masih mendapatkan bantuan dari PT. Orela Shipyard dan PT. PGN Saka yang beroprasi didaerahnya ${ }^{21}$. Bantuan dari PT. Orela yang didapatkan masyarakat nelayan Desa Ngimboh berupa penghalang ombak agar tidak tertutup pasir di muara laut tempat nelayan desa Ngimboh akan melaut. PT. PGN Saka membantu masyarakat nelayan Desa Ngimboh berupa pembuatan Balai Nelayan dan KUB Nelayan yang berfungsi sebagai tempat menjual perlengkapan melaut yang dikelola oleh nelayan sendiri. ${ }^{22}$

Masyarakat Desa Ngimboh dianugerahi dengan potensi laut dan darat yang melimpah, generasi muda desa tersebut tidak berminat untuk mengolah hasil laut maupun pertanian dan memilih untuk menjadi tenaga kerja Indonesia di luar negeri, karena jika bekerja di luar negeri bisa mendapatkan penghasilan yang lebih dari pada menjadi petani atau nelayan. Ketika sudah tidak mampu lagi bekerja di luar negeri sebagai tenaga kerja Indonesia, barulah masyarakat beralih profesi untuk menjadi petani atau nelayan sehingga menyebabkan pengelolaan wilayah pesisir yang ada di Desa Ngemboh menjadi kurang optimal.

Potensi yang dimiliki Desa Tambak Cemandi dalam produksi garam memang sudah diakui sebagai penghasil garam terbanyak se-Kecamatan Sedati, Kabupaten Sidoarjo. Potensi tersebut hilang akibat adanya rencana Pemerintah Provinsi Jawa Timur untuk membangun Sea World sebagai tempat wisata baru di Jawa Timur. Progam pemerintah tersebut sudah masuk kedalam tahap pembebasan lahan, hampir 200 hektar tambak warga desa sudah dijual kepada pengembang. Potensi yang sedemkian besar yang sudah dimiliki turun-temurun oleh masyarakat Desa Tambak Cemandi akan hilang karena adanya kebijakan pemerintah yang ingin membangun

\footnotetext{
Hasil wawancara dengan Zainul Arifin, perangkat Desa Tambak Cemandi Sidoarjo, pada Tanggal 15 Agustus 2015.

Hasil wawancara dengan Kariono, Ketua Kelompok Nelayan Danau Biru Desa Tambak Cemandi Sidoarjo pada Tanggal 15 Agustus 2015.

Lihat Pasal 81 ayat (2) Peraturan Daerah Provisinsi Jawa Timur Nomor 6 Tahun 2012 tentang Pengelolaan dan Zonasi Wilayah Pesisir dan Pulau-Pulau Kecil Tahun 2012 Sampai Tahun 2030 (Lembaran Daerah Provinsi Jawa Timur Tahun 2012 Nomor 4 Seri D).

Hasil wawancara dengan Bayu tokoh pemuda Desa Ngimbuh, Gresik, pada Tanggal 15 Agustus 2015.

Hasil wawancara dengan Umar Said, Ketua Kelompok Nelayan Samudra Desa Ngimboh, Gresik pada Tanggal 17 Agustus 2015.
} 
wilayah Sea World di wilayah tersebut.

MEA yang mulai berlaku pada Januari 2016, belum dirasakan kabarnya oleh masyarakat pesisir Jawa Timur. Nelayan Desa Ngimboh belum mengetahui dengan jelas apa yang dimaksud dengan MEA. ${ }^{23}$ Ketidaktahuan ini akan berdampak buruk jika MEA sudah berjalan. Masyarakat Desa Tambak Cemandi yang memiliki potensi tambak dan garam besar diwilayah Sidoarjo juga tidak mengetahui apa-apa perihal MEA. Masyarakat Tambak Cemandi menganggap bahwa MEA hanya sebuah kebijakan pemerintah perihal perdagangan, yang tidak akan berdampak pada kehidupan sosial dan ekonomi masyarakat Tambak Cemandi. ${ }^{24}$

Pemerintah Daerah tidak pernah mengadakan sosialisasi perihal MEA, sehingga masyarakat awam tidak mengetahui dan menghiraukan dengan adanya MEA sebentar lagi. Kondisi ini sangat mengkhawatirkan, karena komoditas laut seperti udang dan budidaya perikanan kedepannya termasuk dalam list komoditas yang tidak dilindungi. Jika dilihat dari kondisi lapangan dewasa ini di lingkungan pesisir Jawa Timur mutu produk dari budidaya perikanan masih kurang sehingga kedepannya ditakutkan, produk laut Indonesia kalah bersaing dengan produk dari negara anggota MEA.

2. Faktor-Faktor yang Menjadi Kendala Penguatan Budaya Maritim Desa Pesisir di Jawa Timur dalam Menghadapi Masyarakat Ekonomi ASEAN (MEA)

Pembangunan dan penguatan budaya maritim pada desa pesisir di Indonesia khususnya di Jawa Timur tidak seperti membalikkan telapak tangan. Faktor-faktor penghambat proses penguatan budaya maritim utamanya dalam memberdayakan masyarakat desa pesisir guna memanfaatkan potensi pesisir yang ada sangatlah banyak. Apalagi tidak berselang lama akan ada Masyarakat Ekonomi Asean (MEA) yang membuat penguatan dan pembangunan budaya maritim pada desa pesisir menjadi suatu hal yang sangat penting dalam menunjang perekonomian negara. Berdasarkan penelitian yang penulis lakukan pada tiga wilayah berbeda di jawa timur, yaitu wilayah Desa Tambak Cemandi di Kabupaten Sidoarjo, Desa Ngimboh di Kabupaten Gresik, dan Desa Wonorejo Surabaya Setidaknya ada empat faktor utama yang menjadi penghambat penguatan budaya maritim.

Pertama, kurangnya peranan Pemerintah. Upaya yang dilakukan Pemerintah khususnya Pemerintah Daerah dalam optimalisasi potensi pada wilayah pesisir masih belum sepenuhnya dilakukan. Pada Desa Tambak Cemandi Pemerintah melalui Dinas Kelautan dan Perikanan (DKP) Kabupaten Sidoarjo beberapa kali mengadakan studi banding dan sosialisasi kepada nelayan, namun sosialisasi tersebut hanya diikuti beberapa nelayan saja serta tempat pelaksanaannya pun tidak dilakukan di Desa Tambak cemandi sendiri sehingga memakan biaya dan waktu kerja dari nelayan. Begitu juga dengan kegiatan studi banding yang dilakukan oleh Pemerintah yang menurut nelayan setempat kurang memberikan dampak yang signifikan, hal tersebut lantaran kondisi pada lokasi tempat studi banding berbeda dengan wilayah mereka sehingga apa yang didapat dari studi banding tidak dapat diterapkan pada lokasi mereka. Tidak hanya itu, peran pemerintah dalam sosialisasi mengenai MEA pun belum tersampaikan dengan baik, banyak masyarakat pesisir yang belum mengetahui apa itu MEA dan apa tantangan serta hambatannya.

Pemerintah Daerah pun bukannya tanpa ada upaya dalam mengembangkan wilayah pesisir, sebagai contoh pada Desa Tambak Cemandi, Pemerintah Daerah beberapa kali memberikan bantuan berupa jaring, perahu,dan lain-lain, namun jumlah yang diberikan pun sangat sedikit dan kecil sehingga membuat nelayan menjualnya kembali. Berbeda dari Desa Tambak Cemandi, pada Desa Ngimboh pada satu tahun terakhir ini bantuan dari Pemerintah Daerah khususnya kepada nelayan sama sekali tidak ada. Justru bantuan lebih 
banyak datang dari CSR perusahaan swasta dan BUMN yang peduli akan kelangsungan masyarakat nelayan. Perusahaan swasta dan BUMN tersebut adalah PT Orella Shipyard dan PGN Saka Energi yang memberikan bantuan berupa pembangunan infrastruktur seperti pembangunan tempat istirahat nelayan di tepi pantai dan juga bantuan lain berupa pengerukan pasir pada muara sungai.

Kedua, peran masyarakat pesisir yang rendah. Untuk mewujudkan suatu budaya maritim guna menjadikan Indonesia sebagai poros maritim dunia, peranan masyarakat menjadi faktor sentral, utamanya peran masyarakat pesisir. Selama ini masyarakat pesisir cenderung pasif dalam menghadapi permasalahan-permaslahan yang timbul pada wilayah mereka. Bantuan dari Pemerintah meskipun tidak besar jumlahnya, tidak dapat dimanfaatkan dengan optimal dan seringkali mereka jual kembali untuk mendapatkan uang. Tidak hanya itu sosialisasi yang dilakukan Pemerintah seakan-akan tidak dianggap dan mereka biarkan seperti angin lalu. Hal tersebut lantaran mereka menganggap sosialisasi yang dilakukan Pemerintah hanya sebagai teori-teori saja dan tidak sesuai dengan prakteknya. Para nelayan dan masyarakat pesisir lebih menganggap apa yang mereka lakukan lebih tepat dan berjalan baik ketimbang apa yang disampaikan Pemerintah pada sosialisasi. Hal lain dari peran masyarakat yang rendah adalah mengenai masalah sampah di sungai.

Desa Tambak Cemandi dan Desa Ngimboh persoalan mengenai sampah selalu menjadi persoalan yang tidak ada ujungnya. Perahu nelayan yang hendak melaut seringkali tersangkut sampah pada baling-baling mesinnya. Pemerintah Daerah pun sudah beberapa kali melakukan pengerukan di sungai tersebut dan telah menyediakan tempat pembuangan sampah. Kenyataannya upaya yang dilakukan Pemerintah Daerah tidak berdampak apa-apa dan masalah sampah pun terus berlanjut dikarenakan kesadaran masyarakat untuk membuang sampah pada tempatnya tersebut masih kurang, dan lebih memilih membuang sampah ke sungai. Berbeda dengan Desa Tambak Cemandi yang hanya mengandalkan penangkapan ikan dan udang pada Desa Ngimboh nelayan secara sukarela membangun karambah atau dalam bahasa setempat disebut rumpon untuk menambah pendapatan mereka. Rumpon yang dibangun masyarakat merupakan hasil swadaya masyarakat desa Ngimboh sendiri. Rumpon yang digunakan untuk menangkap kerang hijau membawa keuntungan sendiri bagi para nelayan, karena dengan adanya rumpon tersebut mereka dapat terbantu untuk mendapatkan pendapatan disamping pendapatan dari hasil menangkap ikan.

Desa Wonorejo di Surabaya berbeda dari kedua desa sebelumnya. masyarakat Desa ini juga memanfaatkan daerahnya sebagai potensi wisata bahari mangrove sehingga selain mendapat pemasukkan dari hasil melaut, penduduk sekitar juga dapat pemasukkan lewat usaha seperti penjualan ikan bakar sebagai dampak positif adanya pembukaan wisata bahari mangrove.

Ketiga, permodalan. Permodalan menjadi salah satu penghambat dalam upaya pengoptimalisasian budaya maritim. Pemerintah sendiri juga telah memberikan bantuan permodalan kepada nelayan. Sebagai contoh pada Desa Tambak Cemandi nelayan mendapatkan bantuan sebesar 100 juta rupiah dan dibagi kepada tiga kelompok nelayan. Menurut pendapat nelayan sendiri hal tersebut belumlah cukup dikarenakan modal melaut lebih besar dibandingkan pendapatan yang mereka terima. Untuk menutupi kekurangan modal mmereka cenderung bergantung pada tengkulak. Ketergantungan kepada orang lain inilah yang membuat terjadinya adanya siklus yang tidak menguntungkan bagi nelayan.

Nelayan selaku yang bergantung pada pemiliki modal atau biasa mereka sebut sebagai juragan yang sekaligus sebagai pengepul seakan terikat perjanjian bahwa hasil laut yang mereka dapat harus diserahkan kepada juragan sebagai bentuk rasa terima kasih atas modal yang telah dipinjamkan. Hal yang membuat nelayan tidak mampu mendapatkan penghasilan maksimal adalah karena juragan atau pengepul seringkali 
membeli hasil tangkapan nelayan dengan harga sangat murah. Sebagai contoh 1 kilogram ikan dihargai Rp.5.000,00, (lima ribu rupiah) dimana harga tersebut berselisih hampir Rp.2.000 (dua ribu rupiah) jika langsung dijual diluar pengepul. Hal tersebutlah yang menjadi penghambat khususnya nelayan dalam menerima pendapatan yang lebih optimal.

Keempat, pemasaran. Selain masalah permodalan, pemasaran merupakan hal penting yang tidak dapat dipisahkan terkait permodalan. Pemasaran yang dilakukan masyarakat pesisir yang rata-rata berprofesi sebagai nelayan dilakukan melalui perantara pengepul. Seperti dijelaskan pada pembahasan sebelumnya bahwa nelayan yang mayoritas masyarakat kurang mampu untuk dapat melaut mereka membutuhkan modal yang tidak sedikit. Pada akhirnya mereka harus meminjam uang kepada pengepul untuk modalnya. Konsekuensi yang harus mereka terima adalah bahwa hasil tangkapan yang telah didapat harus diserahkan kepada pengepul sebagai bentuk "rasa terima kasih" namun terkadang nelayan menyisahkan separuhnya untuk dijual langsung ke pasar tanpa melalui pengepul untuk mendapatkan hasil yang lebih tinggi. Proses pemasaran yang harus melalui pengepul bukan hanya dilakukan oleh para nelayan, petani tambak pun juga melakukan hal yang sama dalam pemasaran.

Hal tersebut diatas dapat juga diwujudkan dengan sistem resi gudang. Sistem resi gudang telah diatur dalam Permendag Nomor 37/M-DAG/ PER/11/201. Dalam permendag ini salah satu komoditi wilayah yakni rumput laut. ${ }^{25}$ Rumput laut merupakan salah satu potensi sumber daya pesisir yang keberadaannya sangat penting, utamanya dari segi ekonomi masyarakat pesisir yang dapat memanfaatkannya untuk menambah penghasilan masyarakat desa pesisir. Ironisnya dalam ketentuan Permendag Nomor 37/M-DAG/PER/11/2011 tentang Barang yang dapat Disimpan di Gudang dalam Penyelenggaran Sistem Resi Gudang tepatnya pada Pasal 4 diatur bahwa barang yang dapat disimpan di gudang salah satunya adalah rumput laut. Ketentuan mengenai rumput laut tersebut kemudian "hilang" dalam Pasal 11 ayat (2) Perda Jawa Timur Nomor 14 Tahun 2013 tentang Percepatan Pelaksanaan Sistem Resi Gudang yang notabene merupakan peraturan pelaksana di daerah mengenai resi gudang.

Tidak diaturnya mengenai rumput laut dalam barang yang menjadi komoditas unggulan di Provinsi Jawa Timur sejalan dengan adanya pengepul dalam sistem pemasaran produk rumput laut tersebut. Bahkan bukan hanya rumput laut saja yang seharusnya dimasukkan ke dalam ketentuan mengenai komoditas utama mengenai resi gudang, ikan yang merupakan potensi laut yang utama pun seharusnya bisa dimasukkan dalam ketentuan tersebut. Keuntungan yang akan didapat nelayan jika diterapkannya sistem resi gudang atas ikan oleh pemerintah akan membuat pendapatan nelayan akan jauh lebih tinggi dibandingkan jika mereka harus menjualnya kepada pengepul.

Sistem resi gudang merupakan salah satu solusi untuk mengurangi proses permonopolian yang dilakukan oleh para pengepul. Berdasarkan hal tersebut maka seharusnya Pemerintah Daerah khususnya Pemerintah Provinsi Jawa Timur dapat membuat suatu regulasi yang mengatur mengenai resi gudang berkaitan dengan potensi sumber daya pesisir agar para nelayan dapat menjual hasil tangkapannya tanpa melalui pengepul tetapi langsung melalui pemerintah. Hal ini penting untuk dilakukan karena persoalan mengenai pengelolaan dan pemanfaatan sumber daya pesisir sudah seharusnya menjadi tanggung jawab Pemerintah dan sudah seharusnya masyarakat pesisir utamanya nelayan dan petani pesisir mendapat keuntungan yang setimpal atas apa yang mereka lakukan, bukan 
malah kerugian seperti yang terjadi sekarang ini.

Penerapan Sistem Resi Gudang menawarkan serangkaian manfaat yang luas, bagi petani sendiri, dunia usaha, perbankan dan bagi pemerintah. Manfaat tersebut antara lain:

1. Keterkendalian dan kestabilan harga komoditi: sistem ini bermanfaat dalam menstabilkan harga pasar, melalui fasilitasi penjualan sepanjang tahun (all year long). Sebab dengan diterapkannya Sistem Resi Gudang maka pada pasca panen (pada saat biasanya harga komoditi mengalami penurunan drastis), barang-barang komoditi tidak harus langsung dijual, melainkan disimpan dulu di gudang, sesuai dengan standar kebutuhan penyimpanan dari masing-masing jenis barang.

2. Keterjaminan modal produksi: pemegang komoditi mempunyai modal usaha untuk produksi berkelanjutan karena adanya pembiayaan dari lembaga keuangan yang menjadi bagian dari Sistem Resi Gudang.

3. Keleluasaan penyaluran kredit bagi perbankan: dunia perbankan nasional memperoleh manfaat dari terbentuknya pasar bagi penyaluran kredit perbankan. Sistem Resi Gudang di banyak negara dianggap sebagai instrumen penjaminan kredit tanpa risiko, sebab kredit yang diberikan memiliki agunan yang jelas, dengan skema pengembalian kedit sesuai dengan kesepakatan khusus atas perkiraan harga barang dari masingmasing yang disimpan di gudang.

4. Keterjaminan produktivitas: jaminan produksi komoditi menjadi lebih pasti karena adanya jaminan modal usaha bagi produsen/petani. Keterkendalian sediaan (stock) nasional menjadi lebih terjaga. Sistem ini mendukung terbangunnya kemampuan Pemerintah untuk memantau dan menjaga ketahanan sediaan, melalui jaringan data dan informasi terintegrasi yang terbangun oleh Sistem Resi Gudang; hal ini dapat menjadi basis data ketersediaan sejumlah jenis barang guna menangkal terjadinya impor barang yang "liar" terhadap jenis barang yang realitasnya cukup sediaan.

5. Keterpantauan lalu lintas produk/ komoditi: sistem ini membangun kemampuan Pemerintah di pusat dan daerah untuk meningkatkan kualitas komoditi, melindungi konsumen, mengendalikan ekosistem, mengendalikan lalu lintas produk komoditias ilegal, dan sebagainya.

6. Keterjaminan bahan baku industri: sistem Resi Gudang merupakan bagian tidak terpisahkan dari sistem pemasaran dan sistem industri yang dikembangkan di suatu negara guna menjamin ketersediaan bahan baku secara berlanjut.

7. Sistem Resi Gudang telah terbukti mampu meningkatkan efisiensi sektor agrobisnis dan agroindustri, karena baik produsen maupun sektor komersial yang terkait, dapat mengubah status sediaan bahan mentah dan setengah jadi untuk menjadi produk yang dapat diperjualbelikan secara luas dengan telah terlebih dahulu melakukan pengolahan sehingga memiliki nilai tambah.

8. Efisiensi logistik dan distribusi: sebagai surat berharga, Resi Gudang dapat dialihkan atau diperjualbelikan oleh Pemegang Resi Gudang kepada pihak ketiga, baik di pasar yang terorganisir (bursa) atau di luar bursa. Dengan terjadinya pengalihan kepemilikan atau hak atas Resi Gudang tersebut, kepada Pemegang Resi Gudang yang baru, diberikan hak untuk mengambil barang sesuai dengan deskripsi yang tercantum di dalamnya. Dengan demikian akan tercipta suatu sistem perdagangan yang lebih efisien dengan dihilangkannya komponen biaya pemindahan barang secara maual.

9. Kontribusi fiskal: melalui transaksitransaksi Resi Gudang, Pemerintah memperoleh manfaat fiskal yang riil (manifest) dan relatif terkendali, yang 
selama ini bisa jadi hanya bersifat potensial dan belum tentu dapat dikendalikan dengan baik. ${ }^{26}$

Hasil beberapa studi tentang Sistem Resi Gudang menunjukkan adanya potensi yang dapat dimanfaatkan dari pelaksanaan Sistem Resi Gudang utamanya dalam mendukung pembiayaan, minimalisasi fluktuasi harga, peningkatan pendapatan petani, mobilisasi kredit, perbaikan mutu produk dan sebagainya. ${ }^{27}$

\section{Kesimpulan}

Berdasarkan pembahasan hasil penelitain terhadap data yang diperoleh serta didasarkan pada teori yang ada dan telah diuraikan pada bab sebelumnya, maka dapat disimpulkan halhal sebagai berikut: Pertama, bahwa kebijakan penguatan budaya maritim desa pesisir oleh Pemerintah Provinsi Jawa Timur dalam menghadapi Masyarakat Ekonomi Asean (MEA) hingga saat ini belum dilakukan. Fakta yang ada di lapangan masyarakat yang tinggal di wilayah pesisir bahkan sebagian besar tidak mengetahui perihal pasar bebas MEA yang akan dimulai pada Januari 2016. Kebijakan Pemerintah Daerah Nomor 6 Tahun 2012 tentang Pengelolaan dan Rencana Zonasi Wilayah Pesisir dan Pulau-Pulau Kecil tahun 2012-2032, masih belum dapat dirasakan oleh masyarakat desa pesisir. Potensi yang ada di desa pesisir di Jawa Timur belum dapat bersaing di Pasar Bebas Masyarakat Ekonomi ASEAN. Hasil pengelolaan dan pemanfaatan yang masih rendah dari Pemerintah Daerah.

Kedua, faktor-faktor yang menjadi kendala penguatan budaya maritim desa pesisir di Jawa Timur dalam menghadapi Masyarakat Ekonomi ASEAN (MEA) dikarenakan masih minimnya sosialisasi yang dilakukan oleh Pemerintah Daerah, masyarakat desa pesisir bersikap acuh terhadap daerahnya, tidak adanya modal dari pemerintah sehingga nelayan harus meminjam uang dan menjual hasilnya pada pengepul, serta belum adanya pasar untuk menjual ikan segar dan produk olahan masyarakat desa pesisir.

\section{DAFTAR PUSTAKA}

\section{A. Buku}

Harsono, 2009, Distribusi Pendapatan dan Pertumbuhan Ekonomi Petani, Rajawali, Jakarta.

Kementerian Perencanaan Pembangunan Nasional, 2015, Rencana Pembangunan Jangka Menengah Nasional 2015-2019: BUKU I Agenda Pembanguan Nasional, Kementerian Perencanaan Pembangunan Nasional, Jakarta.

Riana, Diana, 2010, Penggunaan Sistem Resi Gudang, UI Press, Jakarta.

S.K.,Wahyono, 2009, Indonesia Negara Maritim, dalam Masalah Perbatasan Wilayah Laut
Indonesia di Laut Arafuru dan Laut Timor, Teraju, Jakarta.

\section{B. Makalah}

Wiratraman, Herlambang P., "Asean Economic Community:AnAnalysis of Legal Framework and Its Implementation", Paper, Regional Workshop: Protection Of People's Right to Land and Natural Resources in Facing The Wave of ASEAN Economic Integration, Bali, 23-24 November 2014.

Iskan, "Komunitas ASEAN 2015: Membangun Kebersamaan untuk Satu Tujuan”, makalah Seminar Nasional Menghadapi ASEAN Community, Jawa Pos, Surabaya, 2011.

Harsono, 2009, Distribusi Pendapatan dan Pertumbuhan Ekonomi Petani, Rajawali, Jakarta, hlm 30. Lihat juga Ashari, "Potensi dan Kendala Sistem Resi Gudang (SRG) untuk Mendukung Pembiayaan Usaha Pertanian di Indonesia”, Forum Agro Ekonomi, Vol. 29 No. 02, 2011, hlm. 8 


\section{Laporan Penelitian}

PKRB-BKF, 2014, Analisa Daya Saing dan Produktivitas Indonesia Menghadapi MEA, Riset Kajian PKRB, Kementerian Keuangan Republik Indonesia, Jakarta.

\section{Artikel Dalam Jurnal}

Ambariyanto dan N.S, Denny, "Kajian Pembanguanna Desa Pesisir Tangguh di Kota Semarang", Jurnal Riptek, Vol. 6, No. II, 2012.

Ashari, "Potensi dan Kendala Sistem Resi Gudang (SRG) untuk Mendukung Pembiayaan Usaha Pertanian di Indonesia”, Forum Agro Ekonomi, Vol. 29, No. 02, 2011.

Fabianto, Muhamad Dio dan Berhitu, Pieter Th,

"Konsep Pengelolaan Wilayah Pesisir Secara Terpadu dan Berkelanjutan yang Berbasis Masyarakat", Jurnal Teknologi, Vol. 11, No. 2, 2014.

Gustina, Amelya, "Analisis Transhipment Pasal 69 ayat (3) Peraturan Menteri Kelautan Perikanan No. 30 Tahun 2012 tentang Usaha Perikanan Tangkap", Jurnal Dinamika Hukum, Vol. 14, No. 2, Mei 2014.

Lasabuda,Ridwan, "Pembangunan Wilayah Pesisir dan Lautan dalam Perspektif Negara Kepulauan Republik Indonesia", Jurnal Ilmiah Platax, Vol. I-2, Januari 2013.

Puspitawati, Diana, "Desentralisasi Pengelolaan Wilayah Pesisir dan Lautan dalam Kerangka Prinsip Negara Kepulauan”, Jurnal Arena Hukum, Vol. 7, No. 2, Agustus 2014.

Putera, Prakoso Bhairawa, "Perspektif dan Peran Ilmu Pengetahuan dan Teknologi dalam Membangun Kemandirian Bangsa pada Tatanan Negara Maritim“, Inovasi: Jurnal Politik dan Kebijakan, Vol. 10 No. 2, Juni 2013.

Sutrisno, Endang, "Implementasi Pengelolaan Sumber Daya Pesisir Berbasis Pengelolaan
Wilayah Pesisir Secara Terpadu untuk Kesejahteraan Nelayan", Jurnal Dinamika Hukum, Vol. 14, No. 1, Januari 2014.

\section{E. Peraturan Perundang-Undangan}

Undang-Undang Dasar Negara Republik Indonesia Tahun 1945.

Undang-Undang Nomor 27 Tahun 2007 Tentang Pengelolaan Wilayah Pesisir dan PulauPulau Kecil (Lembaran Negara Republik Indonesia Tahun 2007 Nomor 84, Tambahan Lembaran Negara Republik Indonesia Tahun 2007 Nomor 4739).

Undang-Undang Nomor 6 Tahun 2014 tentang Desa (Lembaran Negara Republik Indonesia Tahun 2014 Nomor 7, Tambahan Lembaran Negara Republik Indonesia Nomor 5495).

Peraturan Pemerintah Republik Indonesia Nomor 38 Tahun 2007 Tentang Pembagian Urusan Pemerintahan Antara Pemerintah, Pemerintah Daerah Provinsi, dan Pemerintah Daerah Kabupaten/Kota (Lembaran Negara Republik Indonesia Nomor 82 Tahun 2007, Tambahan Lembaran Negara Republik Indonesia Nomor 4737).

Peraturan Daerah Provinsi Jawa Timur Nomor 5 Tahun 2012 Tentang Rencana Tata Ruang Wilayah Provinsi Tahun 2011-2031 (Lembaran Daerah Provinsi Jawa Timur Tahun 2012 Nomor 3 Seri D).

Permendag Nomor: 37/M-DAG/PER/11/2011 Tentang Barang Yang Dapat Disimpan di Gudang Dalam Penyelenggaraan Sistem Resi Gudang

\section{F. Lain-Lain}

Hasil wawancara dengan Bayu, Tokoh Pemuda Desa Ngimboh, Gresik.

Hasil wawancara dengan Umar Said, Ketua Kelompok Nelayan Samudra Desa Ngimboh, Gresik. 